\title{
Impact of weather parameters on abundance of major defoliators of soybean
}

\author{
M.V. MATTI* AND R.O. DEOTALE \\ Department of Entomology, College of Agriculture, NAGPUR (M.S.) INDIA
}

\section{ARITCLE INFO \\ Received : 05.01 .2017 \\ Revised : 04.03 .2017 \\ Accepted : 11.03 .2017}

\section{KEY WORDS :}

Correlation, Regression, Incidence, Spodoptera litura, Thysanoplusia orechalsia, Weather parameters

*Corresponding author: Email:muttumatti@gamil.com

\begin{abstract}
Studies were under taken on seasonal incidence and relationship of weather parameters on major defoliators of soybean during Kharif 2014-15 at the College of Agriculture, Nagpur. Incidence of Spodoptera litura began during $35^{\text {th }}$ standard week $(0.20 \pm 0.12)$ gradually attained maximum $(1.80 \pm 0.11)$ during $41^{\text {st }}$ standard week. Multiple regression analysis revealed that decrease in 1 per cent of morning relative and evening relative humidity would lead to increase of 0.019 and 0.014 mean number of Spodoptera larvae per meter row length. Incidence of Thysanoplusia orechalsia began during $35^{\text {th }}$ standard week $(0.20 \pm 0.15)$ gradually attained maximum $(1.00 \pm 0.12)$ during $42^{\text {nd }}$ standard week. Population was decreased from $43^{\text {rd }}$ standard week onwards, Regression analysis revealed that decrease in 1 per cent of morning relative humidity would lead to increase of 0.010 mean number of larvae per meter row length, decrease in $1^{\circ} \mathrm{C}$ of morning relative humidity would lead to increase of 2.264 per cent foliage damage.
\end{abstract}

How to view point the article : Matti, M.V. and Deotale, R. O. (2017). Impact of weather parameters on abundance of major defoliators of soybean. Internat. J. Plant Protec., 10(1) : 75-78, DOI : 10.15740/HAS/IJPP/10.1/75-78. 